\title{
Comparison Ghrehlin at Obesity Without Metabolic Sydrome With Obesity with Metabolic Syndrome
}

\author{
Rusdiana $^{1 *}$, Maya Savira ${ }^{2}$, Sry Suryani Widjaja ${ }^{1}$ \\ ${ }^{1}$ Departement of Biochemistry, Faculty of Medical Universitas of Sumatera Utara \\ ${ }^{2}$ Departement of Physiology, Faculty of Medical Universitas of Sumatera Utara \\ *Email: rusdiana@usu.ac.id
}

\begin{abstract}
Obesity is principal causative factor in the development of metabolic syndrome and Ghrelin as human natural hormones is involved in fundamental regulatory processof eating and energy balance. Obesity, which has become a global public health problem, is one of the major risk factors for development metabolic syndrome and type 2 diabetes mellitus. This study aimed to analyze the comparison of ghrelin hormone levels in obese with metabolic syndrome and obese non metabolic syndrome. The sample population is obese adults, then we examined the weight, height, waist size, blood pressure, laboratory tests such as blood sugar levels and lipid profile of sample population to separate obese with metabolic syndrome and obese non metabolic syndrome. After we determined each group we measured stress oxidative levels in blood in obese with metabolic syndrome and obese non metabolic syndrome by ELISA method.With statistical analysis using $\mathrm{T}$ test found that there was significant difference of ghrelin hormone levels between obese with metabolic syndrome and obese without metabolic syndrome $(\mathrm{p}<0.005)$.
\end{abstract}

Keyword: obesity,metabolic syndrome, ghrelin hormone

\section{INTRODUCTION}

The incidence of obesity increase rapidly as a result of inactive lifestyle. The energy thst used for daily activity decrease parallels along with advances in technology. Based on WHO data there are 1.6 billion adultswith overweight and 400 nmillion among them are obese (World Health Organization, 2015). Based on research data Riset Kesehatan Dasar in 2007 (Riskesdas, 2013), obesity prevalence in Indonesia generally in the population aged $\geq 15$ years old is $10.3 \%$ (men $13.9 \%$ and women 23.8\%)(Departemen Kesehatan RI, 2009). An individu determined as obese based on Body Mass Index (BMI) it is a simple index of weight-height relationship calculated as weight in $(\mathrm{kg})$ divided by height in $(\mathrm{m})$ squared. One is categorized as obese I when the BMI 25-29,9 and obese II when the BMI BMI >30. Metabolic syndrome is acondition that characterized by visceralobesity, increasing trygliceride levels and glucose and decreasing High Density Lipoprotein (HDL) and hypertension that can cause a greater risk incidence of type 2 DM and cardiovascular deseases (World Health Organization, 2000; Stern M et.al, 2004). Prevalences of metabolic syndrome varies greatly it is caused by uniformity criterias that used to determine, ethnic difference, sex and age. It can be confirmed that metabolic syndrome likely to increase parallels with obesity or central obesity prevalences (Sargowo D et.al, 2011; Carr DB et.al, 2004; Pusparini, 2007).

Ghrelin is a peptide hormone from stomach with growth hormone releasing activity. It is also able to modify glucose and insulin metabolism, blood pressure levels, abiogenesis, and inflammatory processes in experimental conditions.

Ghrelin is a peptide hormone comparising 28 amino acids from a 94 long amino acid precursor proghrelin. It is an orexigenic hormone. It is produced by $\mathrm{x} / \mathrm{A}$ cells of oxyntic glands present in the mucosal layer of the fundus region odf stomach. A great deal of evidence suggests that ghrelin is involved in development of metabolic syndrome and type 2 diabetes mellitus. Ghrelin plays also important role in cardiovascular system. The recent literature suggests that in addition to food intake 
and energy balance, ghrelin also controls glucose metabolism.Furthermore, current evidence suggests that ghrelin could contribute to the metabolic syndrome. It has been shown that ghrelin concentrations are reduced in different pathofisiological conditions including obesity, type 2diabetes and other conditions with metabolic disturbances. Low ghrelin concentrations are also associated with higher prevalence of the metabolic syndrome with progressively lower ghrelin levels in relation to the number of components of the metabolic syndrome (O.Ukkola et.al, 2009; .S.M.Poykko et.al, 2010). It has been shown that ghrelin concentrations are reduced in different pathophysiological conditions including obesity, type 2 diabetes, and other conditions with metabolic disturbances (.R. Barazzoni et.al, 2007). Ghrelin regulates homeostatic food intake, hedonic eating, and is a mediator in the stress response. Total plasma ghrelin and its associations with food intake, hedonic eating, and stress are decreased in obesity, providing evidence consistent with the theory that central resistance to ghrelin develops in obesity and ghrelin's function in appetite regulation may have evolved to prevent starvation in food scarcity rather than cope with modern food excess. Furthermore, ghrelin is associated with metabolic and cardiovascular health, and may have anti-aging effects, but these effects may be attenuated in obesity (Buss J et.al, 2014). Ghrelin is the only known circulating orexigenic factor, and has been found to be reduced in obese humans (Alvarez-Castro P et.al, 2013).

The aim of this study to analyze the comparison ghrelin hormone level at obesity with metabolic syndrome and obesity without metabolic syndrome.

\section{MATERIAL AND METHODS}

This study involved 40 obesity subjects, all of whom were in good health. All subjects gave informed consent. This research was approved by Health Research Ethical Committee, Medical Faculty of Sumatera Utara/HAM General Hospital by Number 595/TGL/KEPK FK USU-RSUP HAM /2016. The inclusion criteria were the obesity people without medical history of diabetes or malignant disease. Subjects devided two groups, one group was obesity with metabolic syndrome and other group was obesity without metabolic syndrome. Each group consisted of 20 subjects. To determine whether the subject of the metabolic syndrome so examination of weight, height, waist size, blood pressure, laboratory tests such as blood sugar levels and lipid profile. Average age samples of obesity with metabolic syndrome $43.9 \pm 11.3$ years and average age sample of obesity non metabolic syndrome $34.55 \pm 10.8$ years

\section{Assays}

All the samples we examined ghrelin hormone level in the serum by ELISA method. Collect plasm with EDTA- $\mathrm{Na}_{2}$ as anticoagulant. Centrifuge samples for 15 minutes at $1000 \times \mathrm{xg}$ at $2-8^{0} \mathrm{C}$ within 30 minutes of collection.Collect the supernatant and carry out the assay immediately. Dilute plasm 1:10, dilute $30 \mathrm{ml}$ of concentrated wash buffer into $750 \mathrm{~mL}$ of wash Buffer with deionized or distilled water. Put unused solution back at $4^{0} \mathrm{C}$. If crystals have formed in the concentrate, we can warm it with $40^{\circ} \mathrm{C}$ water bath.Incubate for 45 minutes at $37^{\circ} \mathrm{C}$, aspirate and wash 3 times, add $100 \mu \mathrm{L} \mathrm{SABC}$ (Streptavidin Conjugate) working solution into each well.Incubate 30 minutes at $37^{\circ} \mathrm{C}$ aspirate and wash 5 times, add $90 \mu \mathrm{L} \mathrm{TMB}$, incubate $15-20$ minute at $37^{\circ} \mathrm{C}$ and then add $50 \mu \mathrm{L}$ stop solution and read at $450 \mathrm{~nm}$ immediately and calculation.

\section{Stastical Analysis.}

Statisical analysis was done using Microstat Statistical programme on an IBM compatible computer. $\mathrm{T}$-tes was use compare $\mathrm{T}$ test found that there was significant difference of ghrelin hormone levels between obese with metabolic syndrome and obese without metabolic syndrome $(p<0.005)$. 


\section{RESULT AND DISCUSSION}

The characteristics of the subjects of this research are shown in Table 3.1. Subjects in this research were not 20 years old. Body Mass Index (BMI) in the samples used in both obesity with metabolic syndrome and obesity non metabolic syndrome is $>27$, in this research the waist size of the samples at the obesity with metabolic syndrome found from $89-119 \mathrm{~cm}$ and waist size of the obesity non metabolic syndrome found $97-117 \mathrm{~cm}$. Fasting Blood Gucose (FBG) in the obesity non metabolic syndrome samples were normal but the obesity with metabolic syndrome range from low to the moderately elevated range. Profile lipid like HDL value of the samples of obesity with metabolic syndrome range $34-60 \mathrm{mg} / \mathrm{dL}$ and HDL value of the samples of obesity non metabolic syndrome range $46-162 \mathrm{mg} / \mathrm{dL}$. Trigliseride value of the samples of obesity with metabolic syndrome range $91-452 \mathrm{mg} / \mathrm{dL}$ and obesity non metabolic syndrome was $46-162 \mathrm{mg} / \mathrm{dL}$. Dividing sample group in to obesity with metabolic syndrome and obesity non metabolic syndrome base on 3 criteria from 5 criteria, that are WS $>102 \mathrm{~cm}$ at male and $>88$ at female, trigliseride levels $\geq 150 \mathrm{mg} / \mathrm{dL}, \mathrm{HDL}<$ $40 \mathrm{mg} / \mathrm{dL}$ at male and $<50 \mathrm{mg} / \mathrm{dL}$ at female, Blood Pressure (BP) $\geq 130 / 85 \mathrm{Hg}$, so can be categorized as obesity with metabolic syndrome or obesity non metabolic syndrome. The result of measuring ghrelin hormone was found the lower value at obesity with metabolic syndrome was $414,56 \mathrm{pg} / \mathrm{ml}$ and the highest value at obesity with metabolic syndrome was $709,14 \mathrm{pg} / \mathrm{ml}$ and the lower value at obesity non metabolic syndrome was $801,20 \mathrm{pg} / \mathrm{ml}$ and the highest was $1335,9 \mathrm{pg} / \mathrm{ml}$.

\begin{tabular}{lll}
\hline & \multicolumn{1}{c}{$\begin{array}{c}\text { Obesity with } \\
\text { metabolic syndrome }\end{array}$} & $\begin{array}{c}\text { Obesity non metabolic } \\
\text { syndrome }\end{array}$ \\
\hline Age & $43.9 \pm 11.3$ & $34.55 \pm 10.8$ \\
BMI & $33.86 \pm 5.0$ & $31.75 \pm 4.0$ \\
Waist size & $107 \pm 10$ & $104 \pm 15$ \\
FBG & $101.85 \pm 50.8$ & $88.49 \pm 7.2$ \\
HDL & $63.2 \pm 23.85$ & $46.05 \pm 6.99$ \\
Trig & $193.15 \pm 88.59$ & $91.9 \pm 32.81$ \\
Sistole & $139.85 \pm 16.3$ & $123 \pm 155$ \\
& & $81.3 \pm 9.1$ \\
Diastole & $87 \pm 8.4$ & $1068 \pm 571.3$ \\
Ghrelin & $561 \pm 314.7$ & \\
hormone & &
\end{tabular}

Table 3.1. Baseline characteristic of the 40 samples

This study aimed to analyze the ghrelin hormone levels in obese with metabolic syndrome and obese non metabolic syndrome,so we used the statistical analysis with $\mathrm{T}$ test found that there was significant difference of ghrelin hormone levels between obese with metabolic syndrome and obese without metabolic syndrome $(\mathrm{p}<0.005)$. This study ghrelin hormone value was highest at obesity without metabolic syndrome and the lower value we found at obesity with metabolic syndrome. Like the preview study that low plasma ghrelin levels are associated with elevated fasting insulin levels and insulin resistance, suggesting both physiological and pathophysiological roles for ghrelin. For this reason, at least theoretically, ghrelin and/or its signalling manipulation could be 
useful for the treatment or prevention of diseases of glucose homeostasis such as type 2 diabetes (Sangiao-Alvarellos S et.al, 2010).

Current evidence suggests that ghrelin could contribute to the metabolic syndrome (M. Tsch“op et.al, 2001; Tomomi Shiiya et.al, 2002). It has been shown that ghrelin concentrations are reduced in different pathophysiological conditions including obesity, type 2 diabetes, and other conditions with metabolic disturbances. Research by Matthias Tschop et al showed that plasma ghrelin concentration has been shown to be lowerin obese Caucasians when compared with lean Caucasians, like research by Tomomi Shiiya et al showed that plasma ghrelin concentration were higher in patients with anorexia nervosa and lower in patients with simple obesity compared with normal -weight control subjects. In my research was not done in lean samples but just at obesity with metabolic syndrome and obesity without metabolic syndrome, and we found that the obesity with metabolic syndrome was lower ghrelin levels than obesity without metabolic syndrome. As we know that Current evidence suggests that ghrelin could contribute to the metabolic syndrome. It has been shown that ghrelin concentrations are reduced in different pathophysiological conditions including obesity, type 2 diabetes, and other conditions with metabolic disturbances. Circulating ghrelin concentrations are also reduced in healthy off spring of type 2 diabetic patients (Ostergard $\mathrm{T}$ et.al, 2003).

\section{CONCLUSION}

The result this study shows that there was significant difference of ghrelin hormone levels between obese with metabolic syndrome and obese without metabolic syndrome $(\mathrm{p}<0.005)$.

\section{ACKNOWLEDGMENTS}

The authors gratefully acknowledge that the present research is supported by Ministry of Researchand Technology and Higher Education Republic Indonesia. The support is under the research grant TALENTA USU of Year 2017.

\section{REFERENCES}

Alvarez-Castro P, Pena L, Cordido F.Ghrelin in obesity, physiological and pharmacological considerations. Mini Rev Med Chem. 2013; 13(4):541-52.

Buss J, Havel PJ, Epel E, Lin J, Blackburn E, Daubenmier J. Associations of ghrelin with eating behaviors, stress, metabolic factors, and telomere length among overweight and obese women preliminary evidence of attenuated ghrelin effects in obesity?. Appetite. 2014;76:8494.

Carr DB, Utzschneider KM, Hull RL et al. Intra-abdominal fat is a major determinant of the National Cholesterol Education Program Adult Treatment Panel III criteria for the metabolic syndrome. Diabetes 2004;53(8):2087-94

Departemen Kesehatan RI, 2009

M. Tsch“op, C. Weyer, P. A. Tataranni, V. Devanarayan, E. Ravussin, and M. L. Heiman, "Circulating ghrelin levels are decreased in human obesity," Diabetes, vol. 50, no. 4, pp. 707-709, 2001.

O.Ukkola, Ghrelin and Metabolic disorders," Current Protein and Peptide Science,vol.10,no.1, pp.27,2009. DOI: $10.2174 / 138920309787315220$ 
Ostergard T, Hansen TK, Nyholm B, Gravholt CH, Djurhuus CB, Hosoda H, et al. Circulating ghrelin concentrations are reduced in healthy offspring of type 2 diabetic subjects, and are increased in women independent of a family history of type 2 diabetes. Diabetologia. 2003; 46: 134-136.

Pusparini. Obesitas Sentral, Sindroma Metabolik dan Diabetes Melitus tipe 2. Universa Medicina. 2007; 28(4):195-204

R. Barazzoni, M. Zanetti, C. Ferreira, et al., "Relationships between desacylated and acylated ghrelin and insulin sensitivity in the metabolic syndrome," Journal of Clinical Endocrinology and Metabolism, vol. 92, pp. 3935-3940, 2007.

Riskesdas 2013. Riset kesehatan dasar

Sangiao-Alvarellos S, Cordido F.Effect of ghrelin on glucose-insulin homeostasis therapeutic implications. Int J Pept. 2010.

Sargowo D, Andarini S. Pengaruh komposisi asupan makanan terhadap komponen sindrom metabolik. J Kardiol Indones. 2011; 32:14-23

S.M.Poykko,E.Kellokoski,S.Horkkoe,H.Kauma, Y.A.Kesaniemi, and O.Ukkola, "Low plasma Ghrelin is associated with insulin resistance, hypertension, and the prevalence of type 2 diabetes" $\quad$ Diabetes, vol.52,no.10, pp.2546-2553,200. https://doi.org/10.2337//diabetes.52.10.2546

Stern M, Williams K, Gonzalez-Villalpando C et al. Does the metabolic syndrome improve identifi cation of individuals at risk of type 2 diabetes and/or cardiovascular disease. Diabetes Care 2004;27(11):2676-81.

Tomomi Shiiya, Masamitsu et al."Plasma Ghrelin Levels in Lean and Obese Humans and the Effect of Glucose on Ghrelin Secretion"JCEM, vol.87,no.1,pp. 240244,https://doi.org/10.1210/jcem.87.1.8129.

World Health Organization. Obesity and overweight fact sheet. IOTF report. 2015. Available at http://www.who.int/mediacentre/factsheets/fs311/en/. Accessed 10 February 2015.

World Health Organization. The Asia Pacific perspective. Redefining obesity and its treatment. World Health Organization. International Association for the study of Obesity and International Obesity Task Force. Melbourne: International Diabetes Institute; 2000. 